\title{
Supply-Side Reform and Exploration for Fresh Agricultural Products Under the "Internet +" Strategy
}

Lingxiao Liu

Xuchang University, Xuchang 461000, Henan, China.

Abstract: Agriculture is the largest industry in China and a pillar industry in the development of the national economy. It turns the world upside down in the ear of "Internet +". The development of traditional agriculture has changed dramatically in the era of "Internet plus". Fresh agricultural products are a new concept and new format of the agricultural economy at present, which is of great significance for improving the income of agricultural products. This paper focuses on the supply-side reform of fresh agricultural products under the "Internet plus" strategy.

Keywords: "Internet +"Strategy; Fresh Agricultural Products; Supply-Side Reform; Exploration.

Under the new situation, the rapid development of network information technology provides new ideas and opportunities for the transformation and upgrading of traditional industries. Especially in the process of agricultural supply-side structural reform, the effective combination of Internet and traditional agricultural production process plays an irreplaceable role in optimizing the allocation of agricultural resources and promoting the green development of agriculture. Next, some thoughts are given for supply-side reform of fresh agricultural products under the "Internet +" strategy.

\section{The impact of "Internet +" on fresh agricultural products supply chain}

\subsection{Networking}

With the advent of the "Internet + " era, the trading mode of fresh agricultural products has changed greatly. The mode of business flow with e-commerce technology as the carrier has become the mainstream. The rapid development of platform economy has promoted consumption enthusiasm to a large extent, broke through the limitation of the traditional time and space and increased the market scale. In particular, the agricultural products in remote rural and mountainous areas is no longer restricted by traditional time and space, which improves the competitive advantage of products and realizes the real market value of products. The timeliness and data nature of Internet technology has changed the lag of traditional agricultural product supply chain in information transmission and market judgment and analysis, improved the matching degree between the demand side and the supply side, and was conducive to meet the decentralized and personalized needs of consumers.

\subsection{Intellectualization}

In the era of "Internet +", the supply chain management of fresh agricultural products is networked, intelligent and digitalized. Specifically, in view of the various links and elements in the fresh agricultural products supply chain, the network information technology is used to achieve the interconnection of all things, such as pesticide residues, temperature and humidity, moisture, soil monitoring, etc. These obtained data are processed by relevant software to construct perfect operation instructions, and then intelligent management system is constructed. In this way, the agricultural production and management

Copyright $(2020$ Lingxiao Liu

doi: $10.18686 /$ ahe.v4i10.2899

This is an open-access article distributed under the terms of the Creative Commons Attribution Non-Commercial License (http://creativecommons. org/licenses/by-nc/4.0/), which permits unrestricted non-commercial use, distribution, and reproduction in any medium, provided the original work is properly cited. 
system has achieved a perfect combination, which is conducive to the effective allocation of agricultural system resources and meets the different needs of fresh agricultural products market.

\section{Specific countermeasures for the supply-side reform of fresh agricultural products under the "Internet + " strategy}

\subsection{Making full use of Internet technology to expand sales channels}

The shelf life of fresh agricultural products is very short. In the traditional sales process, due to the limitations of sales channels, the sales efficiency and level of agricultural products are affected, so the income of farmers is greatly affected. Under the new situation, we can effectively solve this problem through Internet technology and broaden the sales channels. First of all, farmers of fresh agricultural products should keep pace with the times, actively register their own shops on the major e-commerce platforms, and restrict the sale of fresh agricultural products to enterprises and institutions in the surrounding economically developed areas through the convenience of transportation, so as to reduce the intermediate transaction links and effectively improve their own economic benefits. Secondly, the local government should actively cooperate with Taobao, Jingdong and other large-scale online e-commerce platforms, and use the means of unified purchase and marketing to enable farmers' products settle in terminal stores, so as to help farmers establish stable and long-term production contracts with major e-commerce platforms, and realize intensive production to a large extent. Moreover, farmers should make full use of the network platform to carry out publicity and promotion activities, in order to provide targeted and personalized services for the residents in the surrounding economically developed areas.

\subsection{Accelerating the development of green products through Internet technology}

At present, in the process of fresh agricultural products supply-side reform in many places, due to the constraints of many factors, the pace of green agriculture development is slow, and it is difficult to achieve a deeper level of development. Based on this, all localities should keep pace with the times, actively change the concept of development, and formulate a sound policy system to guide farmers to achieve green planting. First of all, the provincial government in agricultural developed areas should actively build a green certification system, clarify the standards of green agricultural products, and enhance the trust of local residents in the green certification system. Secondly, provinces should vigorously support the development of agricultural production enterprises, encourage them to carry out propaganda through network video, text, pictures and other carriers, so as to guide consumers to establish correct cognition. Moreover, all localities should strengthen the remediation of industrial pollution. The strategy of scientific outlook on development needs good ecological environment to support, especially for the health of residents, green ecological agricultural products play an irreplaceable role.

\subsection{Making use of Internet technology to build famous brand}

As the first industry and also traditional industry in China, agriculture has not yet developed more agricultural enterprises with high-value brands in many provinces and cities, especially in the central and western regions, due to the deep-rooted influence of small-scale peasant economy. In order to effectively solve this problem, provincial governments should attach great importance to it, actively guide the establishment of high-quality enterprises, and use the network platform to create wellknown brands. Specifically, in the process of supporting and guiding the sustainable development of enterprises, we should comprehensively consider the comprehensive value of state-owned enterprises. Generally speaking, most state-owned enterprises have strong organizational capacity, which can connect to a wider range of regions, and have strong policy implementation ability, which can ensure the strategic security of China's food resources to a large extent. With the continuous development of media channels in China, the effect of network publicity is getting better and better. Based on this, the major agricultural enterprises can use the network to carry out effective publicity, create their own brand image, and form a good brand effect.

\subsection{Using Internet to build green ecological base}

In the process of China's agricultural supply-side reform, how to ensure the increase of farmers' income has always troubled these people. Based on this, local governments should actively change the development concept and thinking, guide farmers to innovate production mode through Internet technology, and pay attention to increase the added value of products. Specifically, it can realize the effective combination of agricultural production and tourism industry development. For example, for areas rich in tourism resources, the government should pay attention to improving infrastructure, organizing and guiding 
farmers to establish green ecological industrial parks, and then use the network for effective publicity to attract more urban residents to travel. Based on this, the transportation of fresh agricultural products is avoided, the price of agricultural products is increased, and the development of local economy is promoted to a great extent.

\subsection{Establishing and perfecting the logistics system under the guidance of the government}

The "Internet +"technology has played a vital role in the process of agricultural supply-side reform. First of all, local government departments should set up agricultural products network marketing department according to the actual situation, build a logistics system with industry and local characteristics, and integrate enterprise resources, so as to lay a solid logistics foundation for the development of local fresh agricultural products. Secondly, to accelerate the implementation of the concept of "broadband China", the popularity of the Internet has a direct impact on the role of the Internet in the marketing of fresh agricultural products. With the higher the Internet penetration rate, more high-quality, efficient means of production can be bought for agricultural production, meanwhile it can improve the sales efficiency and level of agricultural products, in order to achieve the purpose of reducing costs and opening up the market. In addition, the local government should guide enterprises to establish perfect logistics service standards. The key to online sales is that high-quality fresh agricultural products can reach consumers in time and keep their freshness and quality. The supply-side reform of fresh agricultural products needs continuous innovation and improvement for the service network and facilities support, and also needs to strengthen the interaction between businesses and enterprises, with irreplaceable role played by the government.

\subsection{Paying attention to personnel training and broadening supply channels}

The marketing of fresh agricultural products in different regions depends on the support of human resources to a great extent. In the current process of agricultural production development, the biggest short board is talent. Based on this, the local government should actively respond to the call of the state, pay attention to the training of Internet and modern agricultural talents, improve the computer operation level of farmers, and also pay attention to the in-depth cooperation with universities and training institutions, in order to establish a community of interests, cultivate professional and compound talents with solid theoretical foundation, high professional level and strong practical ability. We will provide high-quality investment promotion services to attract more local high-quality talents who make a living in other places to return home and start their own businesses, so that talents can be "introduced, retained and sustainable development".

\section{Conclusion}

To sum up, with the accelerating process of world integration, the Internet plays an important role in people's life, work and study. The development of all walks of life, making full use of Internet thinking is a manifestation of keeping pace with the times and conforming to the trend. "Internet + agriculture" is an important measure to promote the supply-side reform of fresh agricultural products, and provides new ideas and means for the development of fresh agricultural products. Therefore, in the process of fresh agricultural products supply-side reform, we should play the role of Internet technology in an all-round and multi angle way.

\section{References}

1. Song W, Wang Y. The study of supply-side reform of fresh agricultural products in Baoding under the "Internet +"Strategy. Think Tank Era 2018; (012): 62-63.

2. Hang M. Research on the construction mechanism and countermeasures of Nanning's agricultural product supply chain under the background of "Internet + "_ Based on the thought of agricultural supply-side reform. Rural Economy and Technology 2018; (10): 53+71-74.

3. Guo F, Li C. Research on practice and path of Chengdu's agricultural supply-side reform under the view of "Internet +" B_ Based on the perspective of the high quality development of agricultural supply system. Journal of Chengdu Administration College 2019; (003): 86-91.

4. Gao H, Zhang Y, Li J. Research on the collaborative distribution mode of fresh agricultural products under the background of "Internet +". playing the role of social science and promoting the reform and development of Tianjin-Excellent papers of the twelfth annual academic conference of Tianjin social sciences (Middle); 2017. 